Journal of Sustainable Development of Transport and Logistics

journal home page: https://jsdtl.sciview.net

Shahraki, A. A. (2019). Improvement and development of the railroad transportation, reflection of the case of Iran. Journal of Sustainable Development of Transport and Logistics, 4(2), 37-49. doi:10.14254/jsdtl.2019.4-2.4.

\title{
Improvement and development of the railroad transportation, reflection of the case of Iran
}

\section{Abdol Aziz Shahraki}

Universities of Sistan,

Baluchestan province, Iran

Professor, Researcher

sharaki@kth.se

\section{open 0 access cc dol}

Article history:

Received: September 10, 2019

1st Revision: October 7, 2019

Accepted: November 25, 2019

DOI:

10.14254/jsdtl.2019.4-2.4

\begin{abstract}
This research paper is about the renewal, improvement and development of railroad transportation industry and planning for its contribution to the national and regional economic development. A theoretical exploration provided a guide for the necessary assessments. A research method based on the case study of almost all elements of the Iran railroad transportation system has been performed. The implementation of the observation by means of some indicators proves that hinders shall be removed to achieve maximum profit of the rail transport industry. Strengths, weaknesses, opportunities and threats (SWOT) analysis aided to evaluate the features of the industry. The analysis revealed that the present system of the railroad transportation is unable to assist the national macro economy. The failure corresponds to scarcely investing, funding, managing, infrastructure, operating conditions, and international/regional trade limitations. However, with the help of the improvement plans the prospects for the rail transport development will be pretty satisfactory due to the strategic Geo-policy, climate, nature, and trade potentials. A linear programming for the rail transport industry (LPRTI) has been provided to suggest the ways for maximizing of the rail transport system's profits to support the national macro economy. The outcome of this research paper assists the regional/national economies with the help of a successful railroad transportation industry everywhere in the world.
\end{abstract}

Keywords: rail transport industry, international corridor, infrastructure, marketing, linear programming, macro economy, Iran

Corresponding author: Abdol Aziz Shahraki

E-mail: sharaki@kth.se 


\section{Introduction}

This paper is to see how does the railroad transportation industry contribute to the growth and development of national economy in Iran at the present recession time? Iran's railroad transportation network is visible in the following figure.

Figure1: Network map of Iran railroads

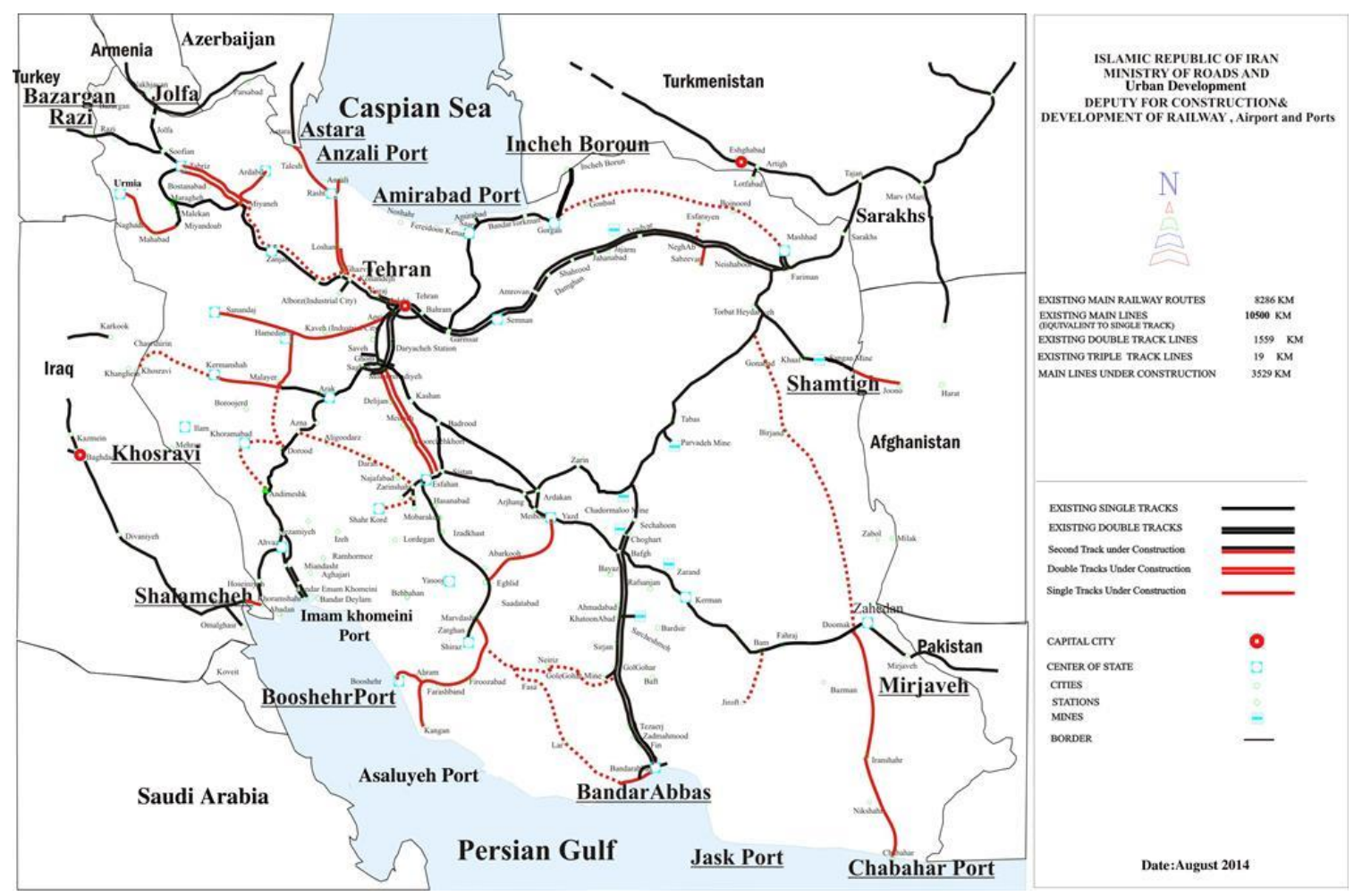

Source: Iran railroads company

As the map displays, Iran is a neighbor of Pakistan, Afghanistan, Turkmenistan, Azerbaijan, Armenian, Turkey, Iraq, the Caspian Sea, the Oman Sea, and the Persian Gulf. It is at the intersection of major Asian, Middle Eastern, and European countries and trade routes. The geographical place of Iran assists it to open rail corridors into surrounding countries. Despite the available opportunities in the Iran's railroad transportation industry such geopolitical importance, diverse climate, human resources, natural assets, and commercial attractions, it does not have a proper role to play in the national economy. Consequently, there is an urgent need for comprehensive enhancement of the railroad infrastructures including track, traction, operation, and utilization. At the present, the implementation of an efficient strategy due to railroad-industry in Iran is hindered due to increase of major obstacles. Hinders are almost observable under an umbrella of rail transport industry analysis. Therefore, a thorough observation is essential for the characterization of the railroad transport role in Iran. This methodology implies the determination of an integral quantitative criterion for the industry quality.

The main question addressed by this paper is: How does the railroad transportation industry contribute to the economic growth in Iran?

The hypothesis of this research is that the railroad transportation industry will help the national economy if it increases its quantities and qualities to meet national and international freight and passenger demands and needs.

The methods applied by this paper are a SWOT (strengths, weaknesses, opportunities and threats) analysis, a linear programming for railroad transportation industry (LPRTI), a system analysis procedure, the applied mathematics and some other classic research methods 


\section{Literature review}

This part provides a theoretical framework for the performance of the case studies based on the theories of the relevant scholars and experts. Iran has a government controlled oil revenue dependent and brokerage commercial economy. (Banks, 2015; Alrifai, 2015; Shin, Choi \& Luo, 2015; Zgheib, 2015; Salehi, 2013; Volk, 2015; Erami \& Keshavarzian, 2015; Agarwala, 2015; Chavoshi, Ahmadinia, \& Feizabadi, 2015; Betz, 2014) studied and explored the various characteristics of Iran's economy and recognized its critical socioeconomic situation. From the other side some scholars mentioned on economic potentials and opportunities, which exist in Iran, see i.e. (Isalou \& Shahmoradi, 2014; Ghanian, Ghoochani \& Crotts, 2014; Poorfaez, et al., 2014 and Ayoubi, Mosalanejad \& Jahromi, 2015). There are plenty researches aiming at the promotion of the railroad transportation industry in macroeconomic plans of Iran, see as samples (Suri \& Mehrotra, 2015; Proost \& Van Dender, 2012; Gholizadeh \& Rabiei, 2015; Rodemann \& Templar, 2014; Solaymani \& Kari, 2014; Shokri, Moosavi \& Dousti, 2013; Kudrin \& Gurvich, 2015; Shariatinia \& Azizi, 2017). As one example Ghaderi, et al. (2015) with the help of a research titled 'Improving the quality of rail freight services argued that a rail transportation development not only does economic development, but also it can place a role in economic growth. The recent economic sanctions, the decrease in economic growth rate and declining of the petroleum revenues into the economy are a principal cause for speculation on using railroad transportation capacities in Iran (Simon, 2018, Shafiee, 2018; Leber, 2018). In terms of overall theories, the optimal use of a rail transport network will contribute to the economic and spatial development of a country. Scholars, i.e. Huang and Kasu have shown the strong association between the development of the railway transportation network and the regional/national economic development (Huang, 2019 and Kasu \& Chi, 2019). In this work, we suppose the existing of the association and examine the validity of this hypothesis in Iran. Let's see what benefits does a railroad transport network have? Profillidis suggested the general advantages of the railroad transportation as follows:

"1. An interconnected several transport units can form a train and it transports about 15,00050000 tons of cargo and a big number of passengers.

2. The railroad transport is with the guided wheel on the track based on the contact of metal with metal. This procedure reduces the resistance movement to $3 \mathrm{Kg} /$ one tone load. So, it requires a much less propulsion force.

3. The railroad transportation is less expensive

4. The rail transport has much less environmental pollution

5. The chance of dying in a road accident is almost eight times the rail transport

6. The privacy land occupied in the railway transport is much less than other systems" (Profillidis, 2000:8).

In addition, features of rail transportation in Iran have been explored in papers authored by researchers from Iran and the world. Some instances are (Keser, 2015; Mostafa, et al., 2015; Mohammadi and Serajian, 2015; Yaghini, et al., 2014; Eluru, et al., 2012; Sivilevičius and Maskeliūnaitė, 2014; Moayedfar, Moghadam and Haghighatpour, 2014 and Yaghini, Momeni \& Sarmadi, 2015) who presented helpful ideas on the related subjects. Sullivan and Sheffrin defined a railroad infrastructure as a fundamental facility and system serving the national economy to function (Sullivan and Sheffrin, 2003). Scholars such Gronalt and Farayi analyze the main components of a general railroad transportation system (Gronalt \& Rauch, 2018 and Darayi et al, 2017). They listed the components of the system and analyzed their functions. To include rather a deep specialized exploration, in particular, a thorough analysis of the rail transport infrastructure system in Iran please sees the following figure. 
Figure 2: The system of railroad transportation industry

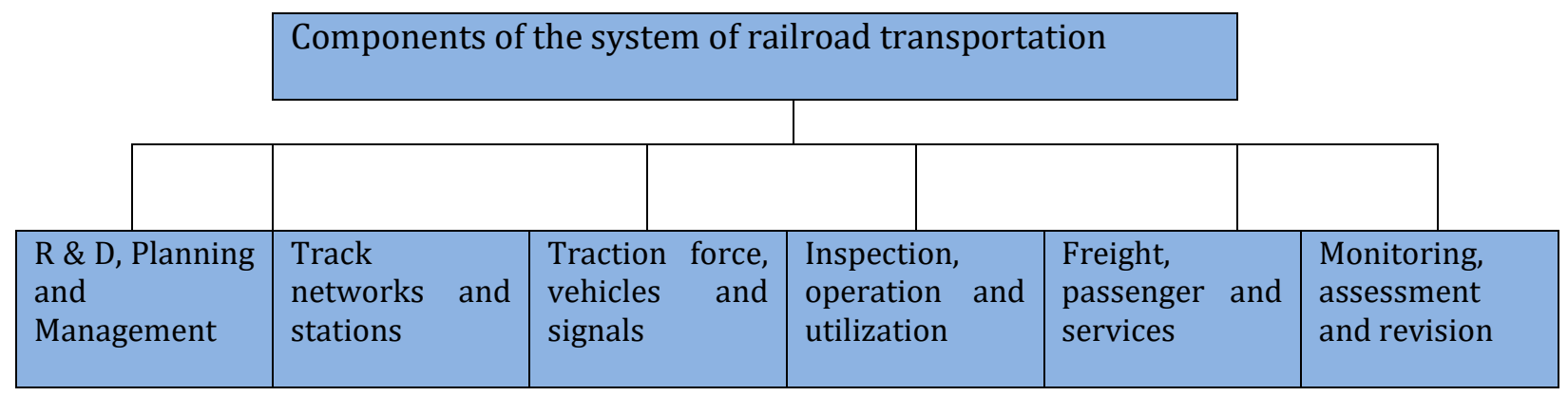

Source: Authors' visualization of system of rail transport industry with its subsystems

In Figure 2, every subsystem encompasses a number of indicators that this study has observed their quantities and qualities. Linked to this system analysis, we provided 6 major subsystems with 40 indicators for the analysis purpose. Table 1 illustrates the six major subsystems of the railroad transportation system with 40 indicators which assist the study of the railroad transportation industry. The 40 indicators have been determined with the help of the literature reviewing, author's field observation and experiences alongside with many researches performed through other scholars.

\begin{tabular}{|c|c|c|}
\hline $\begin{array}{c}\text { Name of main } \\
\text { subsystem } \\
\text { Number of indicators }\end{array}$ & Abbreviations & Indicators \\
\hline $\begin{array}{l}\text { R\&D (Research and } \\
\text { Development), Planning } \\
\text { and management } \\
8\end{array}$ & $\boldsymbol{R}$ & $\begin{array}{l}1 \text { Quality of research projects in terms of science and feasibility. } \\
2 \text { Quality of planning process in terms of pre-studies, planning } \\
\text { methodologies, funding, monitoring and assessment } \\
3 \text { Importance rate of international corridors in the future plans } \\
4 \text { Quality of managerial system regarding selection method, } \\
\text { scientific/individual abilities, team working and responsibility } \\
5 \text { Quality of organizational structure and communicative features } \\
6 \text { Quality of personnel, the process of employment/ recruiting } \\
7 \text { Quality of training programs to personnel and staffs } \\
8 \text { Quality of plans to increase capacity in digitalization, } \\
\text { electrification, modernization and acceleration }\end{array}$ \\
\hline $\begin{array}{l}\text { Networks of tracks and } \\
\text { stations } \\
11\end{array}$ & $\boldsymbol{N}$ & $\begin{array}{l}1 \text { Number of international corridors and their quality in details } \\
2 \text { Quality of rail bearing structures generally } \\
3 \text { Quality of super structure and ballast } \\
4 \text { Quality of rail lines and size of track gauge } \\
5 \text { Quality of sleepers, rail anchoring, rail bearing and bending } \\
6 \text { Formation layer quality in geology, hydrology and seismology } \\
7 \text { Quality of railway's subgrade, rail spike, and rail joint } \\
8 \text { The rate of subgrade resistance against extreme frost and heat } \\
9 \text { Quality of crossing and switch procedures } \\
10 \text { Quality of terminals and stations in terms of suitable location, } \\
\text { load tolerance, vibration tolerance and firmness } \\
11 \text { Quality of train station from aesthetic and attraction views }\end{array}$ \\
\hline $\begin{array}{l}\text { Traction Force, vehicles } \\
\text { and signals } \\
6\end{array}$ & $F$ & $\begin{array}{l}1 \text { Type of locomotive and traction force } \\
2 \text { Type of motor in terms of rated and effective power } \\
2 \text { Quality of locomotive in motor, traction force and energy use } \\
\text { 3The rate of running resistance and starting resistance } \\
4 \text { The quality of brake system and braking distance } \\
5 \text { Quality of railcars in terms of general convenience, comfort } \\
\text { furniture, the rate of vibration and the level of noise pollution } \\
6 \text { Quality of signaling system, and signal circuit/ box }\end{array}$ \\
\hline $\begin{array}{l}\text { Inspection, operation } \\
\text { and utilization }\end{array}$ & $I$ & $\begin{array}{l}1 \text { Quality of standards and acts concerning safety control of train } \\
2 \text { Quality of maintenance system in the time intervals and cost } \\
3 \text { Quality of maintenance in geometrical/mechanical parameters }\end{array}$ \\
\hline
\end{tabular}




\begin{tabular}{|c|c|c|}
\hline 5 & & $\begin{array}{l}4 \text { Quality/precision in operations to repair sinking of track, } \\
\text { longitudinal defect/latitudinal defect of track and lateral damage } \\
5 \text { Quality of mechanical machines and devices for maintenance }\end{array}$ \\
\hline $\begin{array}{l}\text { Services, freight, and } \\
\text { passenger } \\
4\end{array}$ & $\boldsymbol{S}$ & $\begin{array}{l}1 \text { How much the customers are in the center of system? } \\
2 \text { Quality of passenger services, passenger rights an d schedules } \\
3 \text { Quality of freight services, tariff regulation and tracking cargo } \\
4 \text { The integration degree of passenger and cargo services }\end{array}$ \\
\hline $\begin{array}{l}\text { Monitoring, assessment } \\
\text { and revision } \\
6\end{array}$ & $M$ & $\begin{array}{l}1 \text { The importance degree of monitoring and auditing } \\
2 \text { Does the railroad transport industry monitor in practice? } \\
3 \text { Does the industry assess to understand failures/successes? } \\
4 \text { Quality of ex ante and ex post analysis of the regional economic } \\
\text { consequences of the international corridors } \\
5 \text { Does the industry revise based on new findings? } \\
6 \text { Is the organization flexible enough to improve continuously? }\end{array}$ \\
\hline
\end{tabular}

Source: Extracted from the literature reviewing and author's field observation, studies and surveys

The first left column of the table divides the problems of the current rail transport system of Iran into six major groups, representing the number of relevant indicators. The middle column of the table introduces abbreviations of $R$ (Research \&Development, Planning and management), $N$ (Networks of tracks and stations), $F$ (Traction force, vehicles and signals), $I$ (Inspection, operation and utilization), $S$ (Services, freight, and passenger), and $M$ (Monitoring, assessment and revision). In addition, the third column in the rightmost side of the table lists those indicators/problems that relate to the components of the railroad system. As Debbech and colleagues suggest the works to improve the capacities of a railroad transportation network shall be performed simultaneously and collectively ( Debbech, et al, 2018). We also experienced that the interconnection of the railroad transportation system states that efforts to improve all components of the system must be carried out simultaneously, interactively and connectively. The following figure illustrates well the interactions among the indicators. The figure will assist us during the case studies and observation concerning the railroad transportation system.

\section{Figure 3: Connected and interactive indicators to study the railroad transportation system}

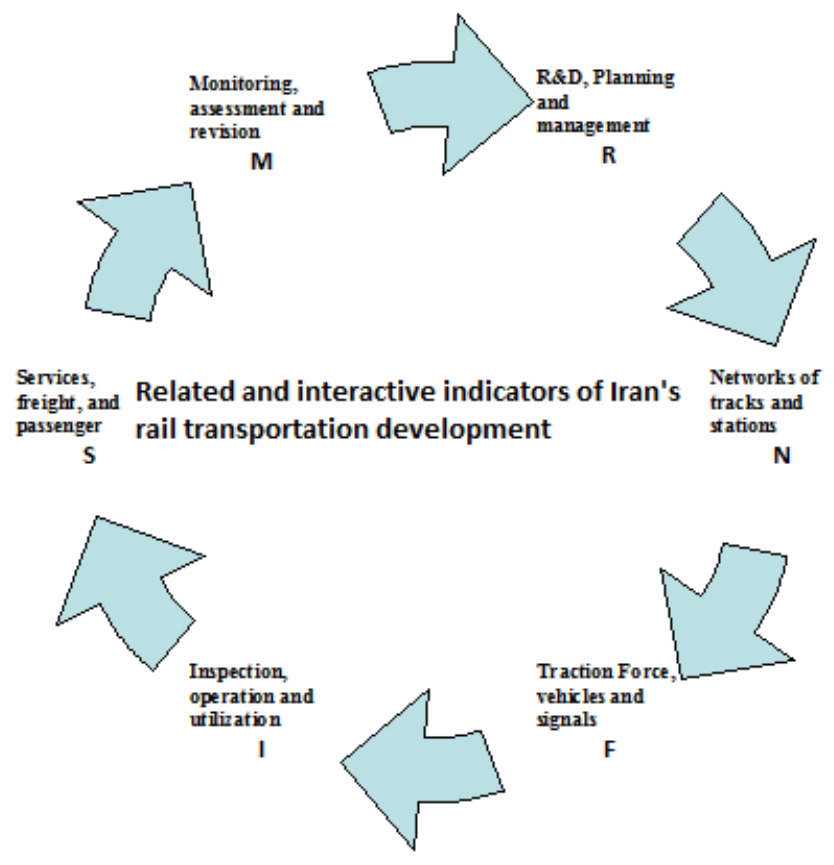

\section{Case studies}

We applied methods to the improvement of the current situation of the railroad transportation system in Iran. The methods assist us to meet optimal economic growth and development in Iran with 
the help of the improvement in the railroad transportation. For this reason the method of SWOT has been used to understand the present strengths, weaknesses, opportunities, and threats in Iran's railroad transportation industry such infrastructure development, marketing analysis, scanning of the resources and analyzing of the transportation incentives. We analyzed the railroad transportation system of Iran with the use of a SWOT technique considering the indicators presented in Table 1. We found that amongst the indicators that prevent the railroad transportation industry to generate the national economic growth and development the international perspective and challenges exist. For example, the 90 kilometers long rail corridor from Zahedan to Pakistan does not fit with the railroad of Pakistan in terms of its track, gauge and switchblade. The Challenges on financing in the six subsystems of Iran's railroad transportation system and investing in the modernization of the industry have been assessed as high ranked obstacles to achieve the maximum revenue for the industry.. In addition, a linear programing for the railroad transportation industry (LPRTI) has been made to improve the present situation of the railroad transportation industry.

This program aimed at maximizing the revenues of the railroad transport system with the help of the set of indicators in Table 1. The linear programming model is to solve a target function and to find solutions to the equations related to the variables (indicators). General scientific methods, social studies, applied mathematics, and statistical methods are also used. Further, a method of systems and structural analysis has been applied to improve the quality of the railroad transportation industry system. Therefore, first, the components of Iran's railroad transportation system have been observed well, the necessary data has been collected, and experiences have been considered. The data have been collected by mean of interviews with experienced managers and experts. Some data reported on the Website of Iran Railroad Transport Company have been used in this research as well. Second, the factors (indicators) that shall be improved to progress the quality and quantity of Iran's railroad transportation industry are determined, see Table 1 . At this stage, the six major groups of variables with 40 sub variables are used to maximize the outcomes of the railroad transportation industry. Third, the way for maximization of the industry's outcomes under conditions of Iran specific situation is suggested. Obviously, in order to improve each indicator in Table 1, measures should be taken in the form of renewal and improvement projects. In the result of carrying out and exploiting the total of these projects, the revenue from rail transport will be maximized. The mathematical interpretation of projects undertaken for the strategic development of the rail transport system is that each group of projects is separately planned and implemented. For example, for group R, we have a sum of all its 8 sub variables.

$$
\begin{gathered}
\max \sum_{j=1}^{n} c_{j} R_{j}, \quad n=8 \\
\text { When } \sum_{j=1}^{8} a_{i j} R_{j}=b_{i}, i=1,2, \ldots, \text { m. In Iran's rail transport we consider } m=n=8
\end{gathered}
$$

We can write the above row vector as a $n \times m=8 \times 8$ matrix, see the following:

$$
b=\left[\begin{array}{l}
b_{1} \\
b_{2} \\
b_{3} \\
b_{4} \\
b_{5} \\
b_{6} \\
b_{7} \\
b_{8}
\end{array}\right] A=\left[\begin{array}{llllllll}
a_{11} & a_{12} & a_{13} & a_{14} & a_{15} & a_{16} & a_{17} & a_{18} \\
a_{21} & a_{22} & a_{23} & a_{24} & a_{25} & a_{26} & a_{27} & a_{28} \\
a_{31} & a_{32} & & & & & & a_{38} \\
a_{41} & a_{42} & & & & & & a_{48} \\
a_{51} & a_{52} & & & & & & a_{58} \\
a_{61} & a_{62} & & & & & & a_{68} \\
a_{71} & a_{72} & & & & & & a 78 \\
a_{81} & a_{82} & a_{83} & a_{84} & a_{85} & a_{86} & a_{87} & a_{88}
\end{array}\right] \times L=\left[\begin{array}{l}
R_{1} \\
R_{2} \\
R_{3} \\
R_{4} \\
R_{5} \\
R_{6} \\
R_{7} \\
R_{8}
\end{array}\right]
$$

Therefore, both the vector and matrix represent the following maximization relationship:

$$
A R=b \quad, \quad M a x C R, \quad 8 \geq R \geq 1
$$

Based on the same reasoning and method, we also write relationships 3 to 7 for other variables, namely; $N, F, I, S$ and $M$.

$$
A N=b \quad, \quad M a x C N, \quad 11 \geq N \geq 1
$$




$$
\begin{array}{llc}
A F=b \quad & \operatorname{Max} C F, & 6 \geq F \geq 1 \\
A I=b \quad & \operatorname{Max} C I, & 5 \geq I \geq 1 \\
A S=b & , \quad \operatorname{Max} C S, & 4 \geq S \geq 1 \\
A M=b & \quad \operatorname{Max} C M, & 6 \geq M \geq 1
\end{array}
$$

In the final stage, the amount of revenues earned from the rail transport industry in Iran is achieved through the following sum of 6 variables with 40 sub-variables or projects:

$$
\sum \operatorname{Irtr}=\operatorname{Max} C R+\operatorname{Max} C N+\operatorname{Max} C F+\operatorname{Max} C I+\operatorname{Max} C S+\operatorname{Max} C M
$$

In the sum of (8) Irtr=Iran's railroad transportation revenues. By simplifying and replacing 6 variables with $\mathrm{P}$, which indicates the projects that shall be carried out to renewal and improvement of the railroad transportation system of Iran, we write the following equation.

$$
\max \sum_{j=1}^{n} c_{j} P_{j} \quad, \quad n=40
$$

When $\sum_{j=1}^{40} a_{i j} P_{j}=b_{i}, i=1,2, \ldots$, m. In this dase we consider $m=n=40$

The equation (9) can also be written as a matrix $m \times n=40 \times 40$

$$
P=\left[\begin{array}{c}
P_{1} \\
\vdots \\
P_{40}
\end{array}\right], b=\left[\begin{array}{c}
b_{1} \\
\vdots \\
b_{40}
\end{array}\right] \text { and } A=\left[\begin{array}{ccc}
a_{11} & \ldots & a_{140} \\
\vdots & \vdots & \vdots \\
a_{401} & \ldots & a_{4040}
\end{array}\right]
$$

Through the above matrix as well as equation (9), the maximum revenue for Iran's railroad transportation industry, aftermath the performances of the 40 projects under the umbrella of the 6 variables of this linear programming can be calculated. To write the target function together with its limitation conditions or with the other word with its inequality equations begins with the following general classic equation:

$$
Y=m X+b
$$
equation.

Here, the six integrated variables have been substituted with $X$ to supply the following target

$$
Z=m_{1} \sum_{n=1}^{8} R_{n}+m_{2} \sum_{n=1}^{11} N_{n}+m_{3} \sum_{n=1}^{6} F_{n}+m_{4} \sum_{n=1}^{5} I_{n}+m_{5} \sum_{n=1}^{4} S_{n}+m_{6} \sum_{n=1}^{6} M_{n}+b
$$

Equation (11) is our target function and we aim to maximize it. In equation (11), the six variables are included and parameters $m_{1}, m_{2}, m_{3}, m_{4}, m_{5}$ and $m_{6}$ are coefficients that the decision makers in the railroad transportation industry will specify according to the macroeconomic preferences. In the equation, the $b$ is a constant depending on the particular conditions that will be determined by the planners as well. Further, we have the limitation equations (equations 12, 13 and 14) report certain constraints in the Iran railroad transportation industry as follow:

$$
\left\{\begin{array}{l}
\text { PTRI } \leq Z \leq 2 \times \text { PTRI } \\
E T N L \leq m_{2} \sum_{n=1}^{11} N_{n} \leq 1.80 \times E T N L \\
0 \leq \sum_{n=1}^{8} R_{n} \leq 1.1 \times 10^{9}
\end{array}\right.
$$

In equation (12), PTRI represents present total revenue of this industry (real number) when the Iran Rail Road Company aims at doubling the total railroad transportation revenue. Equation (13) specifies $1.80 \%$ increase of existing track network length, ETNL, by coming year, according to the announced goal of the Iran Railroad Company. Equation (14) reflects the fact that the company will increase investments in research, planning, managing and development up to $1.1 \times 10^{9} \$$. Other limitations and conditional equations might be written as helpful tools to drive the industry based on 
the macro policies of the industry. We measured the efficiency of the LPRTI model with the efforts of the Iranian Railway Company to develop the railway transportation industry in two periods. Table 2 illustrates data abstracted from the Iran Rail Road Company's yearly reports.

Table 2: The assessment of the subsystems in two time periods
\begin{tabular}{|c|c|c|c|c|}
\hline $\begin{array}{c}\text { Name of main } \\
\text { subsystem }\end{array}$ & Unit & Year of 2016 & Year of 2017 & Increase/percent \\
\hline R & Project & 27 & 11 & $-41 \%$ \\
\hline N & Km. & 10459 & 10475 & $0.15 \%$ \\
\hline F & Devices & 452 & 465 & $2.88 \%$ \\
\hline I & Time & 0 & 0 & 0 \\
\hline S & Tone & $3.6 \times 10^{7}$ & $4 \times 10^{7}$ & $13 \%$ \\
\hline M & Time & 0 & 0 & 0 \\
\hline
\end{tabular}

Source: Statistics on subsystems of the railroad transportation system in Iran, 2017. Available online at: http://www.rai.ir/Index.aspx

In Table 2, the increase for every main subsystem is the result of comparison between the two years. The units are set according to the leading index in the group. For example, in the subsystem group of indicators $\mathrm{N}$, major work has been done to build more railroad lines and we considered the Kilometer as a unit. We maximize the target function of $\mathrm{Z}$ for the years of 2016 and 2017 respectively. In the $\mathrm{Z}$, the coefficients of $m_{1}-m_{6}$ were decided based on the importance of each component of the system and after field and experimental calculations as follows:

$$
m_{1}=0.8, \quad m_{2}=0.8, \quad m_{3}=0.6, \quad m_{4}=0.4, \quad m_{5}=1 \text { and } m_{6}=0.4
$$

We have got $Z_{2016} \cong 3.6 \times 10^{7}$ and $Z_{2017} \cong 4 \times 10^{7}$.

The results are dimensionless real numbers. The presented linear programming makes it possible to maximize the total revenues of the railroad transportation activities through the improvement or renewal projects related to the main groups of variables $R, N, F, I, S$ and $M$ collectively and interactively. The linear programing of the railroad transportation industry (LPRTI) considers the association between maximization of transportation industry and its determinant 6 groups of variables. The calculations through the application of the LPRTI model prove that only $11 \%$ of the targeted development has been achieved.

\section{Discussions and findings}

Some scholars, i.e. (Olsson \& Metzger, 2013), (Snickars, 1989), (snickars, Depeige \& Anoyrkati, 2015) and (Baum-Snow, Brandt, Henderson, Turner, \& Zhang, 2014), proved that the rail transportation industry as a big and growing business in the world. Professional global railroad transportation organizations such as UIC (International union of railways) have a similar idea. Thoreau had anticipated that the railroad transportation industry will bloom again in the world (Thoreau, 2015). However, the railroad transportation industry in Iran has not pursued the anticipated growth tendency so far. Recently, the Iran Railway Company has reported some targets on the industry, i.e. it planned to double its total revenue (see the conditional equation 12). Due to network expanding, it is targeted to build new tracks with a 1.80 times length compared to the existing tracks (see the conditional equation 13). Good news, the company planned to absorb new investments, $1.1 \times 10^{9} \$$ (see the conditional equation 14). The Iran Railway Company reported other facts too, i.e. Table 3 shows total gasoline consumed by locomotives, overall importing/exporting freights via international rail corridors, total internal transported freights, and aggregate passengers travelled by the trains during the year of 2016.

Table 3: Facts on Iran rail transportation industry
\begin{tabular}{|c|c|c|c|c|c|}
\hline Year & $\begin{array}{c}\text { Total national } \\
\text { freight/ thousand } \\
\text { ton }\end{array}$ & $\begin{array}{c}\text { Total exported } \\
\text { freight } \\
\text { /thousand ton }\end{array}$ & $\begin{array}{c}\text { Total imported } \\
\text { freight/thousand } \\
\text { ton }\end{array}$ & $\begin{array}{c}\text { Number of } \\
\text { passengers }\end{array}$ & $\begin{array}{c}\text { Total } \\
\text { gasoline } \\
\text { consumed } \\
\text { /Liter }\end{array}$ \\
\hline 2014 & 32693263 & 361232 & 1900467 & 25533120 & 386487237 \\
\hline
\end{tabular}

Source: Iran Railroad Company 
From an international perspective, Iran has only two corridors namely Tehran-Ankara and Zahedan-Quetta railroads at northwestern and southeastern boarders respectively. From the international view, the small number of the exported freight (only 361232 thousand tons) proves that Iran does not use its potential opportunity to expand trade and business with neighboring countries. Iran has the possibility to build more international corridors. Iran has only two rail corridors with Turkey and Pakistan, but it could have rail corridors with Afghanistan, Turkmenistan, Azerbaijan, Armenian, Iraq, the Caspian Sea, the Oman Sea, and the Persian Gulf as well. The huge volume of gasoline consumption with the locomotives and machineries (386487237 L) reveals the back warding machinery and technology in this industry and the need for its modernization.

At this time, Iran suffers economic problems, high unemployment rate, scary recession, inflation rate, none investment, reducing water resources and degradation of other macro-economic indicators. For more information concerning Iran's economic difficulties, see a report titled "Iran overview", published by the World Bank (Iran overview, World Bank, 2015). This is why Iranian scientists are considering the dynamic railroad transportation industry as a significant source for development of the national economy. Further, the assessments have been made by this research suggested considerable shortages in issues such knowledge-based marketing, necessary technologies, planning procedures, quality and capacity of management, and production of domestic freight, passenger and services.

Our observations show that the efforts improved this industry only $11 \%$ that is a very small figure considering Iran's needs. For the maximization of the rail transport industry, we found the working and failed aspects of the transportation system. The SWOT method has assisted us to specify those aspects. According to the calculations based on the observing of the 40 indicators for the year of 2016, it was determined that the R\&D, planning and management, the $R$ group, has considerable defects compared to the international standards or compared to what Iran needs at this time. The assessment related the network of tracks and stations, $N$ group of indicators, reveals differences between the gauges of internal tracks and neighboring countries (Pakistan) that need new tracks and switching procedures. Therefore, as the Iran Railroad Company wishes the creation of a compatible railroad transportation system with additional international corridors is vital. In addition, major change in the structure and application of the railroad passenger stations is necessary in so far as to become a privileged brand. The assessments marked problems in traction force, vehicles, and signals, $F$ group of the indicators, such as old locomotives with back warding motors. In this group, the analysis suggests modernizing of the locomotives and machineries with new technologies. A big shortage of the knowledge-based planning has been recognized as well. Due to the results of the field studies, the negative impact rate in marketing is noticed. During the studied period, by insufficient marketing was confirmed. The scholars, i.e. (Zondi \& Cassim, 2015; Bickhoff, Hollensen \& Opresnik, 2014 and McDonald \& Wilson, 2011) argued that successful marketing of the railroad transportation industry depends on a precise understanding of the customers' demands and needs. Bad news, Iran's railroad transport industry fails in the quality of service, freight, and passenger, $\mathrm{S}$ group of indicators. It does not include the motivations of the producers, merchants, and passengers as it should do. The qualities of inspection, operation and utilization; I group of indicators, have been studied, A significant gap between what it is in and what it could be has been revealed. A comprehensive set of five indicators that encompasses the main group problem of $I$ was observed. The findings imply that the quality of standards and acts concerning safety control of the train, maintenance system, precision in operations to repair sinking track, longitudinal defect/latitudinal defect of track and lateral damage of line gaps with advanced railroad transport systems. The indicators of the I group should be improved. Regarding the last group $M$ (quality of monitoring, assessment, and revision), the study has not found its existence in the process of the activities and suggests establishing a monitoring and revision mechanism in the industry.

The observing of the 40 indicators associated to six groups' problems from the standpoint of SWOT analyses reveals a number of internal and external obstacles. The analyses found solutions to railroad transportation problems. Application of the classic linear programing of the railroad transportation industry (LPRTI), represented in details, made it possible to maximize capacity for the railroad transportation industry in Iran. The limitations and conditional equations assist the industry to plan its strategic goals. At the same time, the strategic goals for the national economic growth and development should take proper account of the satisfaction of the national and interregional 
transportations' demands and needs, including adequate investments, renewing of old tracks, and modernizing of traction force, etc. The analysis proved that using of the potentials of the rail transportation industry in favor of the national economic development requires efficient and sustainable decision-making in line with adaptive governance of the national macroeconomic policies.

\section{Conclusions}

This paper argued that in the darkness of recent crises in Iran's economy, utilization of its railroad transportation potentials is a light. In which circumstances and with help of which improvements the railroad transportation industry assists the national economy towards growth and development have been analyzed in this research. The strength, weakness, opportunity and threat analysis (SWOT) of the railroad transportation system by means of the field studies have been performed to scan the present situation. The assessment of the 40 indicators which have been introduced in harmony with macro-economic development criteria revealed that the railroad transportation industry is inherently defeated. The failure links to scarcely satisfactory regulations, standards, public participation, track infrastructures, new technologies and machineries, marketing, investment, and regional/international collaboration and cooperation. Then, this paper has used a formulated linear programing of the railroad transportation industry (LPRTI) to plan a prospective development model. The model has been used in two different periods and the outcomes proved yet inadequate development to achieve the announced targets. Prospects for Iran railroad transportation development despite the current problems are quite favorable due to the advantageous Geo-policy, climate, nature, possibilities, potentials, people, and good intention to develop this industry. It has been advised that for maximizing of the railroad transportation industry outcomes the decision makers shall take into account the mentioned advantages of the country and the region. It is important to find solutions to the problems related to the making the rail transportation system modern and progressive in terms of passengers, freights, infrastructure networks, human resources, and international collaboration dimensions. Further, the result of this research advised that the railroad transportation industry in Iran has to satisfy all customers' demands and all private and public sectors' requirements. Therefore, the rule of criteria, standards and acts with a global look in all the affairs has been recommended. An international look and collaborations will assist the industry in funding and knowledge investments. Finally, the output of this research can be a background for performance of improvement, development and management of the railroad transportation industry everywhere.

\section{Appendix A. Supplementary material}

Supplementary data associated with this article can be found, in the online version, at https://jsdtl.sciview.net

\section{Funding}

The authors received no direct funding for this research.

\section{Citation information}

Shahraki, A. A. (2019). Improvement and development of the railroad transportation, reflection of the case of Iran. Journal of Sustainable Development of Transport and Logistics, 4(2), 37-49. doi:10.14254/jsdtl.2019.4-2.4 


\section{References}

Agarwala, P. N. (2014). The new international economic order: an overview. Elsevier.

Alrifai, T. (2015). Islamic Finance and the New Financial System: An Ethical Approach to Preventing Future Financial Crises. John Wiley \& Sons.

Ayoubi, A., Mosalanejad, R., \& Jahromi, M. R. (2015). The Effect of Organizational Effective-Economic Management1 Components on Organizational-Citizenship Behavior in the Agriculture Organization in Fars Province, Iran. Mediterranean Journal of Social Sciences, 6(1), 62.

Banks, F. E. (2015). An Introduction to Oil Economics.

Baum-Snow, N., Henderson, J. V., Turner, M., Brandt, L., \& Zhang, Q. (2015). Transport infrastructure, urban growth and market access in China.

Betz, F. (2014). Control in an Economic System. In Why Bank Panics Matter (pp. 45-65). Springer International Publishing.

Chavoshi, N., Ahmadinia, S., and Feizabadi, B. (2015). The Effect of Recent Years Inflation on the Price of Home Sales in Tehran Case Study: Martyr Beheshti Town.

Darayi, M., Barker, K., \& Santos, J. R. (2017). Component importance measures for multi-industry vulnerability of a freight transportation network. Networks and Spatial Economics, 17(4), 11111136.

Debbech, S., Bon, P., \& Collart-Dutilleul, S. (2018). Improving safety by integrating dysfunctional analysis into the design of railway systems. WIT Transactions on The Built Environment, 181, 399411.

Eluru, N., Bagheri, M., Miranda-Moreno, L. F. \& Fu, L. (2012). A latent class modeling approach for identifying vehicle driver injury severity factors at highway-railway crossings. Accident Analysis \& Prevention, 47, 119-127.

Erami, N., \& Keshavarzian, A. (2015). When ties don't bind: smuggling effects, bazaars and regulatory regimes in postrevolutionary Iran. Economy and Society, 44(1), 110-139.

Ghaderi, H., Namazi-Rad, M. R., Cahoon, S., \& Fei, J. (2015). Improving the quality of rail freight services by managing the time-based attributes: the case of non-bulk rail network in Australia. World Review of Intermodal Transportation Research, 5(3), 203-220.

Ghanian, M., Ghoochani, O. M., \& Crotts, J. C. (2014). An application of European Performance Satisfaction Index towards rural tourism: The case of western Iran. Tourism Management Perspectives, 11, 77-82.

Gholizadeh, A., \& Rabiei, M. (2015). Science Road Journal.

Gronalt, M., \& Rauch, P. (2018). Analyzing railroad terminal performance in the timber industry supply chain-a simulation study. International Journal of Forest Engineering, 29(3), 162-170.

Hilmola, O. P., \& Laisi, M. (2015). Shareholder value creation on deregulated transportation sector: Focus on North American railway freight. Expert Systems with Applications, 42(1), 113-124.

Huang, Y. (2019). The correlation between HSR construction and economic development-Empirical study of Chinese cities. Transportation Research Part A: Policy and Practice, 126, 24-36.

International union of railways. Accessible at: http://www.uic.org/

Iran Railroad Company. Accessible at: http://www.rai.ir/Index

Isalou, A. A., Litman, T., \& Shahmoradi, B. (2014). Testing the housing and transportation affordability index in a developing world context: A sustainability comparison of central and suburban districts in Qom, Iran. Transport policy, 33, 33-39. 
Kasu, B. B., \& Chi, G. (2019). Transportation Infrastructures and Socioeconomic Statuses: A Spatial Regression Analysis at the County Level in the Continental United States, 1970-2010. Spatial Demography, 7(1), 27-56.

Keser, H. Y. (2015). Importance of Transport Corridors in Regional Development: The Case of TRACECA. Sosyoekonomi, 23(24).

Kudrin, A., \& Gurvich, E. (2015). A new growth model for the Russian economy. Russian journal of economics, 1(1), 30-54.

Leber, A. (2018). When the oil runs out: Changing rentier politics in the greater Mediterranean region. Mediterranean Politics, 1-9.

Moayedfar, R., Moghadam, M. S., \& Haghighatpour, P. J. (2014). Calculation of Sight Triangle Dimensions and Unobstructed Area at Railway Level Crossings in Iran.

Mohammadi, S., \& Serajian, R. (2015). Effects of the change in auto coupler parameters on in-train longitudinal forces during brake application. Mechanics \& Industry, 16(2), 205.

Mostafa, R. L., Siavash, Z., Ahmad, M. S., Mohammad, S. A., \& Reza, S. M. (2015). Application of DPSIR Conceptual Model to Evaluate the Impact of Changes in Land Uses to Industrial Zone on the Characteristics of the Ground Waters (Case Study: Mobarakeh Industrial City, Isfahan, Iran).

Olsson, A. R., \& Metzger, J. (2013). Urban Sustainable Development the Stockholm Way. In Sustainable Stockholm (pp. 221-237). Routledge.

Poorfaez, S. E., Mirhoseini, S. M., Rahimi, M., \& Abbasi, L. (2014). How Much Do We Trust: An Experimental Method, The Case Study of Iran. Middle-East Journal of Scientific Research, 19(12), 1690-1698.

Profillidis, V. A. (2000). Railway engineering.

Proost, S., \& Van Dender, K. (2012). Energy and environment challenges in the transport sector. Economics of Transportation, 1(1-2), 77-87.

Rodemann, H., \& Templar, S. (2014). The enablers and inhibitors of intermodal rail freight between Asia and Europe. Journal of Rail Transport Planning \& Management, 4(3), 70-86.

Salehi, M. (2013). An Analysis of Monetary Policy in Iran. Doctoral dissertation, University of Leicester.

Shafiee, K. (2018). Machineries of Oil: An Infrastructural History of BP in Iran. MIT Press.

Shahraki, J., Ahmadi, M., Barghandan, A., \& Saeidian, S. (2014). Examining the Impact of Transportation on Economic Growth in Iran (With a Focus on Marine Transportation). Asian Journal of Research in Business Economics and Management, 4(11), 181-199.

Shariatinia, M., \& Azizi, H. (2017). Iran-China Cooperation in the Silk Road Economic Belt: From Strategic Understanding to Operational Understanding. China \& World Economy, 25(5), 46-61.

Shin, G., Choi, S. W., \& Luo, S. (2015). Do Economic Sanctions Impair Target Economies?

Shokri, A., Moosavi, J., \& Dousti, M. (2013). Study of economic, social and environmental impacts of Olympic Games on the host cities from professors and experts viewpoint Case study: London 2012 Olympic. International Journal of Sport Studies, 3(9), 984-991.

Sifton, J. (2015). Violence All Around. Harvard University Press.

Simon, G. (2018). Modernisation and New Traditionalism in Iran: A Political Economy.

Sindakis, S., Depeige, A., \& Anoyrkati, E. (2015). Customer-centered knowledge management: challenges and implications for knowledge-based innovation in the public transport sector. Journal of Knowledge Management, 19(3), 559-578. 
Sivilevičius, H., \& Maskeliūnaitè, L. (2014). The numerical example for evaluating the criteria describing the quality of the trip by international train.

Snickars, F. (1989). Effects of infrastructure provision on urban economic development. Tijdschrift voor economische en sociale geografie, 80(2), 106-123.

Solaymani, S., \& Kari, F. (2014). Impacts of energy subsidy reform on the Malaysian economy and transportation sector. Energy Policy, 70, 115-125.

Arthur, S., \& Sheffrin, S. M. (2003). Economics: Principles in action'. Upper Saddle River, New Jersey 07458: Pearson Prentice Hall.

Suri, S. C. \& Mehrotra, K. L.(2015). The Indian Institute of Metals Delhi Chapter.

Thoreau, H. D. (2015). The Illustrated WALDEN with Photographs from the Gleason Collection. Princeton University Press.

Volk, L. (Ed.). (2015). the Middle East in the World: An Introduction. Routledge.

World Bank, 2015. Iran overview. Accessible online at: http://www.worldbank.org/en/country/iran/overview

Yaghini, M., Momeni, M., \& Sarmadi, M. (2015). A hybrid solution method for fuzzy train formation planning. Applied Soft Computing, 31, 257-265.

Yaghini, M., Sarmadi, M., Nikoo, N., \& Momeni, M. (2014). Capacity consumption analysis using heuristic solution method for under construction railway routes. Networks and Spatial Economics, 14(3-4), 317-333.

Zgheib, P. (2015). Bribery and Corruption. Business Law and Ethics: Concepts, Methodologies, Tools, and Applications: Concepts, Methodologies, Tools, and Applications, 144.

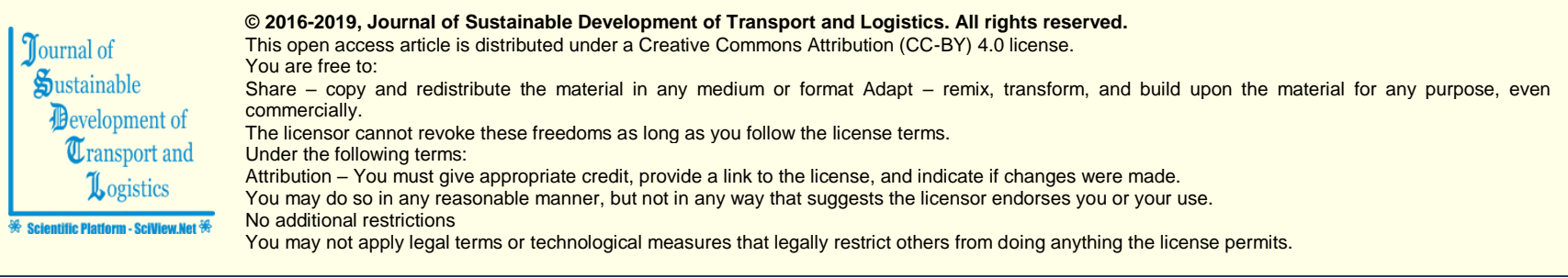

Journal of Sustainable Development of Transport and Logistics (ISSN: 2520-2979) is published by Scientific Publishing House "CSR", Poland,

EU and Scientific Publishing House "SciView", Poland, EU

Publishing with JSDTL ensures:

- Immediate, universal access to your article on publication

- High visibility and discoverability via the JSDTL website

- Rapid publication

- Guaranteed legacy preservation of your article

- Discounts and waivers for authors in developing regions

Submit your manuscript to a JSDTL at https://jsdtl.sciview.net/ or submit.jsdtl@sciview.net 